\title{
The Relationship between Parenting Styles and Alcohol Abuse among College Students in Kenya.
}

\author{
${ }^{1}$ Catherine N. Changalwa, ${ }^{2}$ Michael M. Ndurumo, ${ }^{3}$ Peter L. Barasa \\ and ${ }^{4}$ Moses W. Poipoi ${ }^{\star}$ \\ ${ }^{1,2}$ Department of Educational Psychology, Moi University. \\ ${ }^{3}$ Department of CIEM, Moi University. \\ ${ }^{4}$ Department of Educational Psychology, Masinde Muliro University of Science and Technology.
}

*Corresponding Author's Email: wesangulamp@yahoo.com

\begin{abstract}
Alcohol abuse has adverse health, social and economic effects. Alcohol also affects the brain's mental functions. It is the major cause of indiscipline among college students and affects students' academic performance. Parenting styles are a probable cause of alcohol abuse. Thus the purpose of this study was to investigate the relationship between parenting styles and alcohol abuse among college students in Kaimosi Teachers Training College, Kenya. The study was based on Erikson's (1950) psychosocial theory. The study used survey design and the target population consisted of teacher trainees drinking alcohol. A sample of 32 respondents was sampled using purposive sampling. A selfadministered questionnaire was used to collect data. Data was analysed using descriptive and inferential statistics were used. The study found out that parenting styles have a significant relationship on alcohol abuse among college students.
\end{abstract}

Key words; Alcohol Abuse, Authoritarian parents, College Students, Parenting Styles, Permissive parents.

\section{Abbreviations and Acronyms}

AIDS -Acquired Immune Deficiency Syndrome

HIV- Human Immune Virus

NACADA- National Agency for the Campaign Against Drug Abuse

\section{Introduction}

Alcohol consumption has always been there from the ancient times. In the Bible Jesus made wine from water miraculously (John 2:7-9). Amayo (1994) defines alcohol as a colourless flammable liquid that can intoxicate. This is in line with Steel and Johns (1990) who indicated that drinking alcohol makes an individual relaxed and more sociable. One of the most critical factors destroying children today is alcohol and drug abuse. It is a social malady contributing to rape, crime, academic under achievement, sexual behaviour, addiction, and numerous health, mental health, and emotional disorders (Aquilano, 2008).

To abuse alcohol means to use it in a way that poses a threat to the safety and well being of the user, society or both. Not all people who use alcohol abuse it, and not all people who abuse alcohol are suffering from alcoholism. For example, the individual who drives under the influence of alcohol poses a serious threat to both him/herself and others, but he/she may not suffer from alcoholism (Buskist and Gerbing, 1990).

In Kenya, a survey carried out by National Agency for the Campaign Against Drug Abuse (NACADA, 2000) indicates that Western Province leads the country with $43.3 \%$ of students drinking alcohol every year. College students are not spared either, as records from the Dean of Students Office at Kaimosi College (2008) indicate that on average four students are suspended every term for cases of drunkenness. According to National Baseline Survey (2004), on substance abuse among the youth in Kenya, alcohol abuse is on the increase, with one in every eight people who drink alcohol becoming addicted to it. Report by Njenga in the Daily Nation May $19^{\mathrm{TH}}$, 2008 on alcohol abuse revealed that $70 \%$ of the students are abusing alcohol and the trend has increased four times in the past four years. 
Alcohol abuse results in health effects such as: liver cirrhosis, alcoholic hepatitis, coronary heart disease (heart attack). In liver cirrhosis, the healthy liver cells are replaced by scar tissue (fibrosis), leaving the liver unable to perform its vital functions (Rothschild, 1989). Liver cirrhosis is the major cause of death in the United States (Yoon, 1999). In the year 2000, it was the $12^{\text {th }}$ leading cause of death (NIAAA, 2000).

The main factors that contribute to alcohol abuse as revealed by other studies are heredity and the environment. Njenga (2005) observes that the cause of alcohol - related problems (alcohol abuse) moves in two directions. The environment in which a child is brought up plays a key role. Important factors within the child's environment are; family, home environment, peer group and culture. Early childhood experiences serve to reinforce certain behaviour or discourage them. The parents do this by: setting limits to control their children unacceptable behaviour, serving as important models for their children, and choosing the right neighbourhood for the children. Parenting styles are child rearing practices that parents use to control their children's behaviour. Baumrind (1991) identified three types of parenting styles: Authoritarian, Permissive and Authoritative. Macoby and Martin (1983) identified fourth parenting style-uninvolved parent. The parenting styles play a significant role in developing a child's personality.

Parenting style has been found to predict child well being in the domains of social competence, academic performance, psychosocial development, and problem behaviour.

Baumrind (1991) discovered behavioural characteristics linked to the various parenting styles. The offspring of authoritative parents tended to have the most desirable profiles. These children were friendly with peers, cooperative with adults, independent, energetic and achievement oriented. They also displayed a high degree of selfcontrol. Children with low self- esteem and self -control are likely to abuse drugs (Brenan, 1986). A number of studies have indicated that adolescents who refrain from drinking alcohol have higher self-esteem than do adolescents who drink (Butler, 1980; Young, Werch, \&Bekema, 1989). This association has also been noted in college students. For example, Deky, Levy and Wells (1986) found that alcohol use and depression were associated in college students.

Children whose parents do not set clear rules against or do not monitor alcohol use by children could be at a greater risk for alcohol use (Jackson, Henrickens, \& Dickenson, 1997). Parenting that is relatively low warmth and high in hostility predicted greatest risk of alcohol and other drug use by adolescents (Johnson \& Padina, 1991). In contrast, positive feedback, encouragement, and physical affection from parents predicted lower risk of alcohol use by adolescents (Jackson, et al., 1997).

On the other hand, the tendency to abuse alcohol sometimes runs in families; suggesting a genetic component in alcohol abuse transmission (Annoni, 1990). Further research by Cloninger and Pickens (1991) found out that children of alcoholic parents when compared to the children of non-alcoholic parents are four times likely to become alcoholics when they grow up. This is true even when the children of alcoholics are adopted at birth and raised without the knowledge of the real parents. A study of peer group influence on adolescents showed that, though it's an important factor, it is not the dominant socialization agent (Wortman, 1991). For example, the study showed that peer-group standards are important in matters dealing with manners and choice of friends. In general teens adopt their parents' values on issues that matter-family, religion, work and morals (Sizer et al., 2000). There are young people who reject family values and standards in favour of those of the peer group. This happens for young persons coming from very strict and permissive homes. Adolescents in families where discipline and autonomy are balanced spend more time at home. Peer effects become particularly more powerful when parent-adolescent relationships are of poor quality (Hayes et al., 2004).

Where parents are loving, supportive and maintain standards of behaviour, they enable the child develop competence, autonomy, independence and self- control (Baumrind, 1991). Such children may not suffer from emotional problems. Children whose emotional needs have not been satisfied by parents are likely to seek gratification from the peers; a situation that may cause them to indulge in drug abuse to be accepted by peers (Kizzia and Hagedorn, 1979). Parents thus remain important in the development of values in teens. Poverty may contribute to alcohol abuse in several ways. The parents who brew alcohol for sale directly expose their children to alcohol abuse at an early age. Some families, due to poverty, start brewing the illicit liquor to get income. A child raised up in such a home is introduced to drinking at such an early stage. An article on alcoholism (Daily Nation, $16^{\text {th }}$ July 2005) reports how Michael Shabani ( not his real name)became an alcoholic. Child rearing practice the parent adapts in controlling the child's behaviour may determine the personality. Authoritative parents that are both responsive and demanding may bring up children that are: independent, self-controlled, achievement oriented and co-operative (Baumrind, 1991). These children have high self- esteem and may find it easy to refuse drugs. Alcohol abuse is the leading cause of indiscipline among students at Kaimosi teachers' training college. Despite punitive measures students still abuse alcohol, as every week cases of drunkenness are reported. This prompted the researcher to 
investigate whether the parenting styles could be a probable cause to alcohol abuse. The study sought to investigate the relationship between parenting styles and alcohol abuse among college students, with an aim of minimizing alcohol abuse.

\section{Methodology}

The study was conducted in Kaimosi Teachers Training College in Western Province, Kenya. This study was based on Erikson's psychosocial theory. Erik Erikson (1950) proposed eight life stages through which each person must develop. In each stage, they must understand and balance two conflicting forces, and so parents must choose a series of parenting styles that helps each child as appropriate at each stage. The study used descriptive survey design. Descriptive survey study is the best method for describing a population which is too large to observe directly (Mugenda \& Mugenda, 1991). A sample of 32 was drawn from a total population of 1000 teacher trainees. Thirty two respondents were sampled using purposive sampling. Purposive sampling is a non-random sampling procedure used to select individuals with unique characteristics. By use of records from the Dean of Students' office, four students were identified who had been disciplined for drunkenness. Self-completed questionnaire was used as a tool for data collection. This was appropriate since questionnaires are used to collect basic descriptive information from a broad sample (Kathuri \& Pals, 1993). To determine the content validity of the research instrument, the researcher identified the different types of parenting styles and their influence on alcohol abuse from review of literature. Testretest method of estimating reliability was used to determine the reliability. This method administers the same instrument twice to the same group of subjects at different times. Data was analysed by use of frequency distribution tables and Chi-square.

\section{Results}

The study was to establish the relationship between authoritarian parenting style and alcohol abuse among college students. The responses were summarized and presented in table 1.

Table 1: Distribution of respondents' parents' level of discipline

\begin{tabular}{|l|l|l|l|}
\hline Discipline & Frequency & Percentage & Cumulative \% \\
\hline Punish & 22 & 68.8 & 68.8 \\
\hline Do not punish & 10 & 31.2 & 100 \\
\hline Total & 32 & 100 & \\
\hline
\end{tabular}

The relationship between parenting styles and alcohol abuse was determined as per the research questions. Parenting styles were measured by the level of discipline (strictness of the parent) and love (supportiveness of the parent). The study showed that $22(68.8 \%)$ respondents have parents who punish misbehaviour and $10(31.2 \%)$ who do not (table4.7) This implies that 22 respondents have either authoritative or authoritarian parents as these parents are strict and punish. $10(31.2 \%)$ respondents have either permissive or uninvolved parents who are not strict and do not punish.

Authoritarian parents establish firm rules and expect them to be obeyed without question, thus high in discipline but low in responsiveness. They punish disobedience, however, are not supportive, and democratic. They do not expect their children to express disagreements with their decisions. Misbehaviour is strictly punished. They are thus strict but less supportive. The researcher established that $4(12.5 \%)$ of the respondents taking alcohol have authoritarian parents (table 2).

Table 2: Respondents' perception of parent's discipline and support

\begin{tabular}{|l|l|l|}
\hline Discipline and support & Frequency & Percentage \\
\hline Not supportive and not strict & 2 & $6.25 \%$ \\
\hline Less supportive and strict & 4 & $12.5 \%$ \\
\hline Supportive and strict & 18 & $56.25 \%$ \\
\hline Supportive and not strict & 8 & $25 \%$ \\
\hline
\end{tabular}


The authoritarian parents also don't discuss rules with their children and are thus not democratic. From the study 4 respondents had parents who are not democratic and 28 respondents had democratic parents as shown in table 3.

Table 3: Respondents with democratic parents

\begin{tabular}{|l|l|l|}
\hline democratic & Frequency & Percentage \\
\hline No & 28 & $87.5 \%$ \\
\hline Yes & 4 & $12.5 \%$ \\
\hline
\end{tabular}

The authoritarian parents also acknowledge the use of physical punishment such as caning. It was observed that 4 of the respondents have parents using the cane and 28 who don't use the cane (Table 4).

Table 4: Respondents with caning parents

\begin{tabular}{|l|l|l|}
\hline Canning & Frequency & Percent \\
\hline No & 4 & $12.5 \%$ \\
\hline Yes & 28 & $87.5 \%$ \\
\hline
\end{tabular}

These findings indicate that $4(12.5 \%)$ students abusing alcohol have authoritarian parents.

The research findings concur with Weiss and Schwartz (1996) who found out that college students who abuse drugs have authoritarian parents. The following hypothesis was tested to determine the relationship between authoritarian parenting style and alcohol abuse among college students:

$\mathrm{Ho}_{1}$ : There is no significant relationship between authoritarian parenting style and alcohol abuse among college students.

A chi-square test was performed to examine the relationship between authoritarian parenting style and alcohol abuse among college students. The relation between the variables was significant, $x^{2}(1,32)=25, p<0.05$.

\section{Table 5: Respondents' perception of parents' level of love and discipline}

\begin{tabular}{|l|l|l|}
\hline Parenting style & Frequency & Percentage \\
\hline High love and high discipline & 18 & $56.25 \%$ \\
\hline High love and low discipline & 8 & $25 \%$ \\
\hline Low love and High discipline & 4 & $12.5 \%$ \\
\hline Low love and low discipline & 2 & $6.25 \%$ \\
\hline
\end{tabular}

Authoritative parents though punish; they are warm and supportive to their children, an important factor in controlling alcohol and other drug abuse. The researcher found out that $18(56.25 \%)$ of the respondents who drink have authoritative parents (table 5). These parents are high discipline and high in love. This implies that there is a relationship between authoritative parenting style and alcohol abuse. The findings of this study disagrees with Brenan(1986) who found out that high self esteem is an important factor in preventing drug abuse. According to Baumrind (1991) children of authoritative parents have high self esteem which is a protective factor against drug abuse.

The following hypothesis was tested to determine the relationship between authoritative parenting style and alcohol abuse among college students:

$\mathrm{Ho}_{2}$ : There is no significant relationship between authoritative parenting style and alcohol abuse among college students.

A chi-square test was performed to examine the relationship between authoritative parenting style and alcohol abuse among college students. The relation between the variables was significant, $x^{2}(1,32)=8.125, p<0.05$. Table 5 shows that these parents show a lot of love to their children but are low in discipline. This suggests that permissive parenting style has an influence on alcohol abuse. The findings concur with Darling (1993) who found out that children of permissive parents have high self-esteem but inconsistent discipline, and impulsive behaviour, which may lead to alcohol abuse.

The following hypothesis was tested to determine the relationship between permissive parenting style and alcohol abuse among college students:

$\mathrm{Ho}_{3}$ : There is no significant relationship between permissive parenting style and alcohol abuse among college students. 
A chi-square test was performed to examine the relationship between permissive parenting style and alcohol abuse among college students. The relation between the variables was significant, $x^{2}(1,32)=6.625, p<0.05$.

Table 6: Parents' involvement in the respondent' activities

\begin{tabular}{|l|l|l|}
\hline Parent involvement & Frequency & Percent \\
\hline Involved & 30 & $93.75 \%$ \\
\hline Not involved & 2 & $6.25 \%$ \\
\hline
\end{tabular}

Uninvolved parents are neither demanding nor responsive. This means they are low in discipline and low in love (table 5). They don't punish disobedience and are not involved in their children's activities hence not strict and not supportive. It was also observed in table 6 that 2(6.25\%) respondents have parents who are not involved in their activities, hence the term uninvolved parenting style. This implies that there is a relationship between uninvolved parenting style and alcohol abuse among college students. The findings of the study concurs with Baumrind ( 1991) who observed that children of uninvolved parents have low self esteem , which according to Brenan (1986) makes them vulnerable to drug abuse.

The following hypothesis was tested to determine the relationship between uninvolved parenting style and alcohol abuse among college students: students.

$\mathrm{Ho}_{4}$ : There is no significant relationship between uninvolved parenting style and alcohol abuse among college

A chi-square test was performed to examine the relationship between uninvolved parenting style and alcohol abuse among college students. The relation between the variables was significant, $x^{2}(1,32)=28.25, p<0.05$.

\section{Discussion}

The findings of the study revealed that there is a significant relationship between authoritative parenting style and alcohol abuse among college students. A higher proportion of students abusing alcohol have authoritative parents. These findings are contrary to the findings of Baumrind (1991) who found out that authoritative parent by being warm and supportive to their children help to develop a high self-esteem, which according to Brennaan (1986) is an important factor in controlling drug abuse. They also disagree with Jackson, Henrickson, Foshee(1998) who found out that parental nurturance, associated more highly with authoritative parenting, was inversely related to adolescents' reported susceptibility to peer pressure and deviant self image, both which are significantly high risk factors for alcohol use and misuse. The above results suggest that setting limits being warm and supportive is not sufficient to control alcohol abuse. In addition, there is need to monitor the use of the unsupervised free time as higher proportion of students indicated they drink because of leisure. Borawski (2003) observed that when male adolescents were able to negotiate more unsupervised time they were 1.85 times likely to drink alcohol, while female adolescents were 1.58 times likely to drink.

The results of the study revealed that there is a significant relationship between authoritarian parenting style and alcohol abuse. Baumrind (1991) found out that children of authoritarian parents have low self esteem. This makes them vulnerable to drug abuse (Brennan, 1986). Further study by Johnson and Padina (1991) also indicate that parenting that is relatively low in warmth and high in hostility predicted greater risk of alcohol and other drug use. This also agrees with Weiss and Schwarz (1996) who found out that college students using drugs had unengaged and authoritarian parents. The findings of this research further concur with a study by Cohen and Rice (1997), that found out that students who smoke and drink perceive their parents as less authoritative than students who do not. In Kenya, authoritarian style is the dominant parenting style hence a lot of emphasis is put on physical punishment where the cane is used as the saying goes, 'Spare the rod and spoil the child'. Parents and teachers insist on the use of corporal punishment and in so doing confuse discipline and punishment. Punishment is an external force for controlling behaviour. External forces are effective to appoint. Children will obey when the external force or threat is present but revolt against it when the force is removed. So, when the parents leave children on alone or not under their control, the often do what they want because there's no internal sense of right and wrong present.

Discipline uses internal and external force to teach right and wrong. Parents use external force and model or guide children about right and wrong. This involves explaining first the dos and don'ts before punishing them . Hence they understand why certain things should not be done including alcohol abuse. Authoritarian parents tend to use spanking as a method of external force which is ineffective. Children will do what they are told to avoid spanking but do what they want to do when no one is around to spank them. Flogging is only one tool that parents can use. If a 
parent has only a hammer to fix everything that is wrong in their home, they will break more things than they can fix! The better option is to have a toolbox full of parenting tools. This implies that punishment without internal controls is not sufficient. Most parents though are still using corporal punishment and they see nothing wrong in children being flogged. However, the Ministry of Education realizing that it does not instil discipline abolished it (Wangari Report, 2000). Research by Swinford (2000) show that reliance on physical force as a means of discipline and punishment to control behaviour leads to child maladjustment and deviancy in adolescents and beyond; and inhibits development of internal controls. With this authoritarian parenting milieu, it is not surprising that students of authoritarian parents abuse alcohol.

Research findings showed that there is a significant relationship between permissive parenting style and alcohol abuse among the college students. These findings concur with Darling (1993) who observed that lack of limits over behaviour makes children to grow without self-control and consequently indulge in drugs. This insinuates that self esteem per-see is not enough in controlling drug abuse as students of permissive parents despite the fact that they have high self esteem most of them are abusing alcohol. When parents set limit this helps the child to know what is acceptable and what is unacceptable in the society hence control their behaviour. Also Wood (2004) found out that where parents were more permissive towards alcohol use, their adolescents were more likely to engage in heavy binge drinking. From the study, uninvolved parenting style has a significant influence on alcohol abuse. Baumrind (1991) observed that children of uninvolved parents have low self esteem and lower control over impulsive behaviour. Children with low self esteem and self control are likely to abuse drugs (Brennan 1986). The findings also concur with Jacob and Leonard (1988) who found out that inadequate parenting, which is characterized by lack of affection, inconsistent discipline and supervision, and general lack of involvement, provides the foundation for the development of an aggressive, antisocial behaviour including drug abuse.

\section{Conclusion}

On the basis of the results of this study the it was concluded that Authoritative parenting style has the greatest influence on alcohol abuse among college students, as a higher proportion (56.25\%) of students abusing alcohol have authoritative parents. This implies there is a significant relationship between authoritative parenting style and alcohol abuse.

Permissive parenting style follows authoritative parenting style. There a significant relationship between permissive parenting style and alcohol abuse among college students as $25 \%$ students abusing alcohol have permissive parents. Authoritarian parenting style also has influence on alcohol abuse among college students, $12.5 \%$ students of authoritative parents abuse alcohol. This implies there is a relationship between authoritarian parenting style and alcohol abuse. Uninvolved parenting style has the least influence on alcohol abuse among college students as it had the lowest proportion (6.25\%) of students abusing alcohol.

Thus the following recommendations are made to teachers, parents, curriculum developers and policy makers: teachers and curriculum developers should involve parents in controlling alcohol abuse in children consequently in college students; There is need to provide enough recreation facilities for students to occupy them fully during their free time because other than parenting styles a higher proportion of the students indicated they drink for leisure; and Guidance and counselling should be enhanced for students abusing alcohol instead of punitive measures.

\section{References}

Amayo, G.N. \& Wangai, P. (1994) Handbook for primary \& secondary teachers' guidelines in drug dependence preventive education. Nairobi: Lama Limited Printers.

Anantharaju, A. (2003). Liver transplantation for alcoholic liver disease. Alcohol research \& health, 27(3): 257-269.

Anderson, E. \& Quest, W. (1983). Young children in alcoholic families. Journal of primary Prevention: 174-178.

Annoni, G. (1990). Albumin and collagen gene regulation in alcohol. Gastroenterology, Pgs.197-202.Abuse and Neglect, 6(2): 141-145.

Bagnall, G. (1990). Alcohol, drugs and AIDS-related risks. AIDS Care. 2(4), 309-317.

Barrow, C. (1996). Family in the Cribbean: Themes and perspectives. Kingston, Jamaica: Ian Randle.

Baumrind, D. (1991). The influence of parenting style on adolescent competence and substance use. Journal of Early Adolescence, 11(1): 56-95.

Barber,B,K .(1996).Parental psychological control: Revisiting a neglected construct. Child Development, 67(6), 32963319.EJ 545015.

Brennan, A.F. (1986). Alcohol use and abuse in college students ": 449-474. 
Bronfenbrenner .(1977).Toward an experimental ecology of human development. American psychologist 52: 513-531 Brook, J.S. and Cohen, P. (1990). The psychosocial etiology of adolescent drug use: A family interactional approach. Genetics, Social and General Psychology Monographs 116(2): 111-267.

Bukatko, D. and Daehler, M. (1992). Child development. A Tropical approach. Boston: Houghton Mifflin Company.

Buskist, W., \& Gerbing, D. (1990). Psychology. Boundaries and Frontiers. London: Foresman and company.

Chassin, L. (1996). Relation of parental alcoholism to early adolescent substance use: A longitudinal follow up study. Journal of Abnormal psychology, 05(1):70-80.

Clair, D., \& Genest, M. (1986) Variables associated with adjustment of offspring of alcoholic. Journal of Studies and alcohol: 345-355.

Clarke, P. (2000). Please teacher don't beat me. Jamaica Gleaner Online. Retrieved May 3, 2002, from http://www.jamaicagleaner/gleaner/ 2000103/yout/youth1.html.

Cloninger, C .R. (1985). Inheritance of alcohol abuse: cross fostering analysis of adopted men. Archives of General Psychiatry. 36: 861-868.

Cohen, D.A, \& Rice, J. (1997). Parenting styles, adolescent substance use, and academic achievement. Journal of Drug Education. 27: 199-211.

Cotton, N.S. (1979). The familial incidence of alcoholism; a review. Journal of studies on Alcohol. 40: 89-116.

Darling, N., \& Steinberg, L. (1993). Parenting style as context: An integrative model. Psychologicalbulletin, 113(3): 487-496.

Durkin, K. (1999).Social bond theory and binge drinking among college students: a multivariate analysis. College Student Journal, 33: 450-472.

Evans, H., \& Davies, R. (1997). Overview issues in childhood socialization in the Caribbean. In J. L. Rooparine \& J. Brown (Eds.), Caribbean families: Diversity among ethnic groups pgs. 1-24. Greenwich, CT: Ablex.

Feldman, R.S. (1996). Understanding Psychology. New York: McGraw-Hill Inc.

Frias-Armenta, M. (2002). Long-term effects of child punishment on Mexican women: A structural model. Child Abuse and Neglect, 26: 371-386.

Garlie, A.F and Marguerite, M. (1977). Psychology for living. New York: McGraw-Hill Inc.

Gary, R.C. (1988). Christian Counselling a comprehensive guide. London: Word Publishing.

Goodwin, D.W. (1978). The genetics of alcoholism. Alcohol Health and Research World, 2(3): 2-12.

Hamner, T. J., \& Turner, P. H. (2001). Parenting in contemporary society. Boston: Allyn \& Bacon.

Hawkins, J. D. (1997). Exploring the effects of age of alcohol use initiation and psychosocial risk factors on subsequent alcohol. Journal of studies on alcohol, 2 ,

Hayes, L. (2004). Parenting influences on adolescent alcohol use.:30-40.Melbourne: Impact Print.

Jackson, C., Henriksen,L., \&Dickinson, D.(1997).Alcohol specific socialization, parenting behaviours and alcohol use by children. Journal of studies on alcohol, 60: 362-367.

Jackson, C., Henriksen,L., \&Foshee, V.(1998). The authoritative parenting index: predicting health risk behaviours among children and adolescents. Journal of Health Education and Behaviour ,25: 319-337.

Jacob, T., and Johnson, S. (1997). Parenting influences on the development of alcohol abuse and dependence. Alcohol health and research world.

Jacob, T., \& Leonard,K., (1988). Alcoholic spouse interaction as a function of alcoholism subtype and alcohol consumption interaction. Journal of Abnormal Psychology, 97: 231-237.

Johnson, V. \& Pandina,R. J.(1991). Effect of family on adolescent substance use, delinquency, and copying styles. American Journal of drug abuse, 17: 71-88.

Kalant,H. (1990). Stress related effects of ethanol mammals. Critical reviews in Biotechnology. 9(4): 265-272.

Kandel, D.B., \& Andrews, K. (1987). Process of adolescent socialization by parents and Peers International Journal of Addictions, 22: 319-342.

Kaplan, H. B., \& Lin, C. (2000). Deviant identity as a moderator of the relation between negative self-feelings and deviant behavior. Journal of Early Adolescence, 20: 150-177.

Kothari, C. R. (2003). Research Methodology, Methods and Techniques. New Delhi:Wishwa Prakshan.

Kerlinger, F.N. (1983). Foundations of Behavioural Research(2 $2^{\text {nd }}$ Edition).New Delhi:Surjet Publications.

Kendeler, K.S. (1992). Twin study of alcoholism in women. Journal of American Medical Association, 14, 1877-1882.

Landmann, J., Grantham-McGregor, S. M., \& Desai, P. (1983). Child rearing practices in Kingston, Jamaica. Child Care, Health and Development, 9: 57-71.

Leo-Rhynie, E. A. (1997). Class, race, and gender issues in child rearing in the Caribbean. In J. L. Rooparine \& J. Brown (Eds.), Caribbean families: Diversity among ethnic groups (25-56). Greenwich, CT: Ablex.

Maccoby, E. E., \& Martin, J. A. (1983). Socialization in the context of the family: Parent-child interaction. In P. H. Mussen (Ed.) \& E. M. Hetherington (Vol.Ed.), Handbook of child psychology: Vol. 4. Socialization, personality, and social developmentp. (1-101). NewYork: John Wiley. 
Macgregor, R.R. (1988). Alcohol and drug as co-factors for AIDS. Advances in alcohol \& Substance Abuse. 7(2): 4771.

Maynard, N.J. (1982). Child Study. Mexico: Oxford University Press.

Miller, N. B., Cowan, P. A., Cowan, C. P., \& Hetherington, E. M. (1993). Externalizing in preschoolers and early adolescents: A cross-study replication of a family model. Development psychology, 29(1): 3-18.

Miller N.B., \& Jang, M. (1977). Children of alcoholics. Social Work Research Abstract.

Mugenda,O.M.,\&Mugenda, A.G.(1999). Research Methodology, Quantitative and Qualitative Approaches. Nairobi: African Centre for Technology Studies(ACT) Press.

National Institute on Alcohol Abuse and Alcoholism (1997). Youth Drinking: Risk factors and consequences, alcohol alert No. 37.

Njenga, (2005). Alcohol \& You. Daily Nation, Nairobi: Nation Printers.

Pickens, R.W. (1991). Heterogeneity in the inheritance of alcoholism. Archives of general psychiatry. 48: 19-28.

Pillai, R. (1990). Response to Alcohol, Sex \& AIDS. Alcohol \& alcoholism. 25(6): 711-713.

Pohorecky, L.A. (1991). Stress \& Alcohol interaction. Alcoholism: Clinical \& Experimental Research. 15(3): 438 459.

Rice, F. P. (2000). Human development: A life-span approach. Upper Saddle River, NJ: Prentice Hall.

Rnold, E. (1982). The use of corporal punishment in child-rearing in the West Indies. Child Abuse and Neglect, 6(2), 141-145.

Rothman. K.J. (1980). The proportion of cancer attributable to alcohol consumption. Preventive Medicine, 9(2): 174179.

Rothschild, M.A. (1989). Alcohol induced Liver disease. Alcohol heath and Research world.

Rubin, R. (1999). Effect of ethanol on platelet function. Alcohol Experimental Research, 23(6): 1114-1118.

Sadara, S.W. (1993). Stress-related problem drinking and alcohol problems. Canadian Journal of Behavioural Science, 25(3): 446-464.

Sharpe, J. (1997). Mental health issues and family socialization in the Caribbean. In J. L. Rooparine \& J. Brown (Eds.), Caribbean families: Diversity among ethnic groups. Greenwich, CT: Ablex.

Sloley, M. (1999). Parenting deficiencies outlined. The Jamaica Gleaner Online. Retrieved. April2, 2002, from http://www.jamaicagleaner/1999117/news/n1.html.

Smith, M. G. (1989). Poverty in Jamaica. Kingston, Jamaica: University of the West Indies.

Swinford, S. P., DeMaris, A., Cernkovich, S. A., \& Giordano, P. G. (2000). Harsh physical discipline in childhood and violence in later romantic involvements: The mediating role of problem behaviors. Journal of Marriage and the Family, 62(2): 508-519.

Teacher' Service Commission (1986). Code of Regulation for Teachers

Walker, S. P. (1998). School performance in adolescent Jamaican girls: Associations with health, social and behavioral characteristics, and risk factors for dropout. Journal of Adolescence, 21: 109-122.

Weiss, L.H., Schwarz, J.C. (1996).The relationship between parenting types and older adolescents, academic achievement and substance use: 2101-2114.

Wikimedia Foundation, Inc. Wikipedia:The Free Encyclopedia. http: //en.wikipedia.org

Yorburg, B. (2002). Family realities: A global view. New Jersey: Prentice-Hall. 